\title{
The knowledge-risk-behaviour continuum among young Ugandans: what it tells us about SRH/HIV integration
}

\author{
Raquel Palomino González ${ }^{1}$, Damazo Twebaze Kadengye ${ }^{2,4^{*}}$ and Roy William Mayega ${ }^{3}$
}

\begin{abstract}
Background: With a human immunodeficiency virus (HIV) prevalence of 2.1\% among 15-24 year olds, opportunities for further integration of sexual and reproductive health (SRH) and HIV prevention services for young people in Uganda exist. We examine a range of factors that contribute to variance in risky sexual behaviour among young Ugandans.

Methods: A cross-sectional, nationally representative household survey was conducted between February and March 2016. The questionnaire used assessed knowledge, attitudes and practices related to SRH among young people aged 10-24 years. A composite indicator was constructed to assess risky sexual behaviour, defined as being involved in sexual relations under the influence of alcohol or drugs, engaging in sexual activities without a condom, and having multiple sexual partners in the 6 months preceding the survey. Exploratory analysis was conducted to provide descriptive statistics. Logistic regression was conducted to determine the factors associated with risky sexual behaviour. This analysis focuses on the sub-category aged 15-24 years, comprised of 2725 respondents.

Results: Knowledge levels of family planning (FP), sexually transmitted infections (STIS) and HIV across all respondents were high (above 82\%). Self-reported perceived risk of STIs and pregnancy was consistently higher among 20-24 year old respondents, with $61.5 \%$ feeling at risk of STIs compared to $46.2 \%$ of $15-19$ year olds. A total of $22.7 \%$ of respondents reported having been involved in risky sexual behaviour. Factors associated with risky sexual behaviour among the 15-19years group included gender, single orphanhood, casual work, schooling status, FP knowledge and self-perceived risk of STIS/HIV. For the 20-24 year old respondents, significantly associated factors included gender, educational level, relationship to head of household, place of residence, and self-perceived risk of pregnancy.

Conclusions: Despite high general SRH/HIV knowledge and perceived risk of pregnancy and HIV, risky sexual behaviour among young Ugandans remains high. Effectiveness gaps in the integrated SRH/HIV response for young people should be addressed and targeted interventions focused on holistic prevention at individual level through information, risk awareness, and skill development should be combined with interventions targeting social structures affecting individual behaviour.
\end{abstract}

Keywords: SRH, HIV, Knowledge, Risk perception, Sexual behaviour, Young people, Uganda

\footnotetext{
* Correspondence: dkadengye@gmail.com; dkadengye@aphrc.org

${ }^{2}$ African Population and Health Research Center, Manga Cl, Nairobi, Kenya

${ }^{4}$ School of Statistics and Planning, Makerere University, Kampala, Uganda

Full list of author information is available at the end of the article
}

(c) The Author(s). 2019 Open Access This article is distributed under the terms of the Creative Commons Attribution 4.0 International License (http://creativecommons.org/licenses/by/4.0/), which permits unrestricted use, distribution, and reproduction in any medium, provided you give appropriate credit to the original author(s) and the source, provide a link to the Creative Commons license, and indicate if changes were made. The Creative Commons Public Domain Dedication waiver (http://creativecommons.org/publicdomain/zero/1.0/) applies to the data made available in this article, unless otherwise stated. 


\section{Background}

The possible benefits derived from linkages between $\mathrm{SRH}$ and HIV at the policy, systems and service delivery levels are today widely recognized [1-6]. The renewed emphasis on the SRH/HIV integration agenda, which seeks to reshape health service provision for SRH and HIV services by providing comprehensive health services and referrals in this area [7], can be an effective way of accelerating the achievement of 90-90-90 targets [8] and advancing the Sustainable Development Goal (SDG) 3 target to end the AIDS epidemic by 2030 [9].

For young people in particular, SRH/HIV integration is expected to deliver increased uptake of both SRH and HIV services, improved knowledge of HIV status, promotion of safer sex, reduction in HIV-related stigma and discrimination, better client experience and improved satisfaction, greater support for dual protection and better understanding and protection of individuals' rights $[1,10]$. In Uganda, SRH/HIV integration has taken place at policy, systems and service delivery level since 2012, when the AIDS Control Programme and the Reproductive Health Division of the Ugandan Ministry of Health were mandated to advance this agenda [11]. Integration of SRH and HIV into all care and treatment services was reflected as a strategic objective of the National Strategic Plan for HIV\&AIDS 2011/12-2014/15 [12], and from then onwards in the major policies, strategies and guidelines dealing with SRH and HIV in the country [13, 14].

The effectiveness of the SRH/HIV integrated response achieved at national level can be measured using the list of indicators developed by the Interagency Working Group on SRH and HIV Linkages across 8 different domains. Indicators include, among others, the percentage of adults aged 15-49 who have more than 1 sexual partner in the past 12 months and report use of condom during last sex, and the HIV prevalence rate among young people [15]. When looking at how Uganda performs on these indicators, and despite the government commitment to accelerate the rollout of this agenda at both national and local levels, significant gaps still exist in relation to SRH/HIV outcomes among young people.

An estimated 67 new young Ugandans get infected with HIV every day. This represents $44.1 \%$ of all new infections in the country, the majority of which are sexually transmitted [14]. The HIV prevalence rate among those aged 15-24 years stands at 2.1\% [16]. Young women in particular are at significant risk for both unintended pregnancy and HIV infection. HIV prevalence among 15-24 year olds is 4 times higher among women (3.3\%) than men $(0.8 \%)$ [16], and $23.5 \%$ of young girls aged 15-19 years have given birth [17].

Significant grounds for further integration of SRH/ HIV services for young people in Uganda still exist [18]. Empowering young Ugandans to reduce HIV risk exposure is a fundamental deliverable for SRH and HIV integration, and a more detailed understanding of key factors that contribute to variance in SRH/HIV risk behaviour among young Ugandans can help design interventions that effectively reduce HIV risk exposure among this target group. The objective of this study was therefore to establish knowledge levels, attitudes and practices related to sexual and reproductive health among young people in Uganda.

\section{Methods \\ Study design}

A cross-sectional household survey was conducted in Uganda between February and March 2016. The study targeted a nationally-representative sample of households calculated based on the UN Department of Economic and Social Affairs' practical guidelines on designing household survey samples [19]. The overall household sample size was 2976 households. Sample size calculations were based on the following assumptions: confidence level set at 95\%, percentage of young people age 10-24 who have comprehensive knowledge about HIV/AIDS set at $40 \%$, design effect of 2.0, non-response rate of 20\%, a margin of error/ precision of $10 \%$ and an estimated average 1.48 respondents aged 10-24 years per household.

Given the research questions selected for this paper which focus on sexual activity and SRH/HIV knowledge, the study sub-category aged 15-24 years comprised of 2725 respondents was selected. Young Ugandans aged 10-15 years were excluded given their reduced exposure to sexual activity and to SRH/HIV information as per national guidelines on sexuality education [20].

\section{Sampling}

The first stage of sampling involved a random selection of 44 districts from the sampling frame of all districts in Uganda which were proportionately allocated to the 10 Uganda Bureau of Statistics (UBOS) statistical regions according to their total populations. Kampala was however purposively sampled due to its unique socioeconomic and demographic characteristics. The second stage involved selecting enumeration areas (EA) using the UBOS 2014 National Population and Housing Census sampling frame [21]. A total of 149 EAs (20 households per EA) were selected and allocated proportionately to the 44 sampled districts, so that districts with larger populations were allocated more EAs. The third stage involved assigning a number to each EA household and randomly selecting the ones to be interviewed by applying a numeric interval. A questionnaire was administered to all eligible and consenting persons aged 10-24 years found in the selected households. 


\section{Measurements}

For the present paper, measurements of interest are (a) family planning (FP) knowledge measured by awareness of at least one modern contraceptive method, (b) knowledge of sexually transmitted infections (STIs) measured by having ever heard about any infections that people can get from sexual intercourse, (c) comprehensive knowledge of HIV/AIDS measured by a composite indicator of awareness about HIV, knowledge about its transmission and correctly rejecting three out of five common misconceptions about HIV/AIDS, (d) self-reported perceived risk of being infected with STIs including HIV, and (e) self-reported perceived risk of becoming pregnant or impregnating a girl being rated as "at risk" versus "not at risk". The outcome of interest being risky sexual behaviour was defined by a composite indicator of behaviour that increases one's risk of contracting STIs (including HIV) and/or unintended pregnancies, namely being involved in sexual relations under the influence of alcohol or drugs, engaging in sexual activities without a condom, and having multiple sexual partners in the 6 months preceding the survey.

\section{Statistical analysis}

Data was analysed using STATA 15. Exploratory analysis was conducted to provide descriptive statistics for adolescent's socio-demographic characteristics. Logistic regression was conducted to determine the association between background characteristics of young people, their SRH/HIV knowledge, perceived SRH/HIV risk and being involved in risky sexual behaviour. Statistical analysis was conducted both at bivariate and multivariate level. All variables explored at the bivariate level were retained at multivariate level in order to document those with potential for correlation.

\section{Ethical considerations}

Ethical approval for the study was obtained from Mildmay Uganda Research Ethics Committee and research approval from the Uganda National Council of Science and Technology. Due to the young age of the group targeted by the study and the sensitivity of the research topic, a number of ethical considerations related to the appropriateness of the research and the confidentiality, privacy and consent of the respondents arose.

The research questions and data collection tools used in the study were adapted from existing studies validated for use in the context where this study was conducted. In addition, they were discussed with relevant stakeholders and adapted to the existing national guidelines on age-appropriateness [20]. Potential risks related to the sensitivity of information provided by respondents were mitigated by the use of anonymous identifiers in form of study numbers on the questionnaires, thus de-linking the data collected from specific individuals. In addition, all respondents were interviewed individually in a private place within the homestead, ensuring parents/guardians did not listen in on the discussions. Finally, participation in the research was based on full informed consent of respondents, including verbal consent from parents/legal guardians for those less than 18 years of age.

\section{Results \\ Background socio-demographic characteristics of respondents}

A total of 2725 young people aged 15-24 years were interviewed, representing a $98 \%$ response rate. Background characteristics of the respondents by age group are given in Table 1. Majority in both age groups $(81.8 \%)$ were from rural areas. Almost half (46.5\%) of the 20-24 year old respondents were ever married or cohabitated, compared to $9.8 \%$ of the respondents aged 15-19 years. Moreover, $75.9 \%$ of $20-$ 24 year old respondents were out of school, when compared to $28 \%$ of those aged 15-19 years. It was also observed that $10.9 \%$ of younger respondents were household heads or spouses. Finally, $17.7 \%$ of respondents across both age groups did not have a filial or marital relationship to the household head.

\section{SRH/HIV knowledge, risk perception and risky sexual behaviour among respondents}

Table 2 shows distribution of respondents' SRH and HIV knowledge and risk indicators by age group. Overall, knowledge levels of FP, STIs and HIV across all young people were high (above $82 \%$ ), with the older age group (20-24 years) displaying consistently higher levels of knowledge ( $7 \%$ higher on average) than the younger age group. Awareness of at least one modern FP method was high for both age groups, at an average of $94 \%$. No major differences were observed between knowledge of STIs and comprehensive knowledge of HIV with a similar average of 85.6 and $86.2 \%$ across respondents for both indicators. Self-perceived risk of STIs (including HIV) and pregnancy among all respondents was high, with about half of all respondents reporting to feel at risk. For 20-24 year old respondents, self-reported perceived risk was consistently higher, with $61.5 \%$ feeling at risk of STIs compared to $46.2 \%$ of 15-19 year olds. Further, a combined proportion of $22.7 \%$ of respondents reported to have been involved in risky sexual behaviour exposing them to STI/HIV and/or pregnancy. Prevalence of risky sexual behaviour among the older group (34.6\%) was more than double that of $15-19$ year olds (14.9\%). 
Table 1 Distribution of participants by background characteristics

\begin{tabular}{|c|c|c|c|}
\hline \multirow[t]{2}{*}{ Variable } & $\begin{array}{l}15-19 \text { years, } \\
n=1647\end{array}$ & $\begin{array}{l}20-24 \text { years, } \\
n=1078\end{array}$ & $\begin{array}{l}15-24 \text { years, } \\
n=2725\end{array}$ \\
\hline & Freq. (\%) & Freq. (\%) & Freq. (\%) \\
\hline \multicolumn{4}{|l|}{ Residence } \\
\hline Urban & $261(15.8)$ & $236(21.9)$ & $497(18.2)$ \\
\hline Rural & $1386(84.2)$ & $842(78.1)$ & $2228(81.8)$ \\
\hline \multicolumn{4}{|l|}{ Marital status } \\
\hline Never married & $1484(90.2)$ & $576(53.5)$ & $2060(75.7)$ \\
\hline Ever married & $162(9.8)$ & $501(46.5)$ & $663(24.3)$ \\
\hline \multicolumn{4}{|l|}{ Gender } \\
\hline Male & $741(45.0)$ & $520(48.2)$ & $1261(46.3)$ \\
\hline Female & $906(55.0)$ & $558(51.8)$ & $1464(53.7)$ \\
\hline \multicolumn{4}{|l|}{ Schooling status } \\
\hline In school & $1184(72.0)$ & $258(24.1)$ & $1442(53.1)$ \\
\hline Out of school & $461(28.0)$ & $814(75.9)$ & $1275(46.9)$ \\
\hline \multicolumn{4}{|l|}{ Education level attained } \\
\hline None & $18(1.1)$ & $21(2.0)$ & $39(1.4)$ \\
\hline Some primary & $833(50.6)$ & $422(39.2)$ & $1255(46.1)$ \\
\hline Secondary and above & $794(48.3)$ & $633(58.8)$ & $1427(52.4)$ \\
\hline \multicolumn{4}{|l|}{ Relation to household head } \\
\hline Head/spouse & 179 (10.9) & $458(42.5)$ & $637(23.4)$ \\
\hline Son/daughter & $1165(70.7)$ & $441(40.9)$ & $1606(59.0)$ \\
\hline Other relative & $303(18.4)$ & $178(16.5)$ & $481(17.7)$ \\
\hline \multicolumn{4}{|l|}{ Parents' status } \\
\hline Both parents alive & $1181(71.7)$ & $650(60.4)$ & $1831(67.2)$ \\
\hline One parent alive & $330(20.0)$ & $291(27.0)$ & $621(22.8)$ \\
\hline Both parents dead & $136(8.3)$ & $135(12.5)$ & $271(10.0)$ \\
\hline \multicolumn{4}{|l|}{ Occupation } \\
\hline Student & $1003(61.0)$ & 203 (18.9) & $1206(44.4)$ \\
\hline Peasant & $263(16.0)$ & $369(34.4)$ & $632(23.3)$ \\
\hline Casual works & $286(17.4)$ & 411 (38.3) & $697(25.7)$ \\
\hline Unemployed & $91(5.5)$ & $91(8.5)$ & $182(6.7)$ \\
\hline \multicolumn{4}{|l|}{ Region } \\
\hline Central 1 & $198(12.0)$ & 128 (11.9) & $326(12.0)$ \\
\hline Central 2 & $164(10.0)$ & $103(9.6)$ & $267(9.8)$ \\
\hline East Central & 228 (13.8) & $107(9.9)$ & 335 (12.3) \\
\hline Eastern & $218(13.2)$ & $156(14.5)$ & $374(13.7)$ \\
\hline Kampala & $73(4.4)$ & $79(7.3)$ & 152 (5.6) \\
\hline Karamoja & $43(2.6)$ & $39(3.6)$ & $82(3.0)$ \\
\hline North & $153(9.3)$ & $88(8.2)$ & 241 (8.8) \\
\hline South West & 255 (15.5) & $185(17.2)$ & $440(16.1)$ \\
\hline West Nile & $135(8.2)$ & $54(5.0)$ & 189 (6.9) \\
\hline Western & $180(10.9)$ & 139 (12.9) & $319(11.7)$ \\
\hline
\end{tabular}

Table 2 SRH/HIV knowledge and perceived risk by age group

\begin{tabular}{|c|c|c|c|}
\hline \multirow[t]{2}{*}{ Variable } & $\begin{array}{l}15-19 \text { years, } \\
n=1647\end{array}$ & $\begin{array}{l}20-24 \text { years, } \\
n=1078\end{array}$ & $\begin{array}{l}15-24 \text { years, } \\
n=2725\end{array}$ \\
\hline & Freq. (\%) & Freq. (\%) & Freq. (\%) \\
\hline \multicolumn{4}{|l|}{ FP knowledge } \\
\hline Yes & $1499(91.3)$ & $1056(98.0)$ & $2555(94.0)$ \\
\hline No & $142(8.7)$ & $22(2.0)$ & $164(6.0)$ \\
\hline \multicolumn{4}{|c|}{ Knowledge of STIs } \\
\hline Yes & $1326(82.0)$ & $964(91.2)$ & $2290(85.6)$ \\
\hline No & $291(18.0)$ & $93(8.8)$ & $384(14.4)$ \\
\hline \multicolumn{4}{|c|}{ Knowledge of HIV/AIDS } \\
\hline Yes & $1379(83.7)$ & $970(90.0)$ & 2349 (86.2) \\
\hline No & $268(16.3)$ & $108(10.0)$ & $376(13.8)$ \\
\hline \multicolumn{4}{|c|}{ Perceived risk of STIs } \\
\hline At risk & $761(46.2)$ & $663(61.5)$ & $1424(52.3)$ \\
\hline Not at risk & $886(53.8)$ & $415(38.5)$ & $1301(47.7)$ \\
\hline \multicolumn{4}{|c|}{ Perceived risk of pregnancy } \\
\hline At risk & $657(39.9)$ & $567(52.6)$ & $1224(44.9)$ \\
\hline Not at risk & $990(60.1)$ & $511(47.4)$ & $1501(55.1)$ \\
\hline \multicolumn{4}{|c|}{ Risky sexual behaviour } \\
\hline Yes & $245(14.9)$ & $373(34.6)$ & $618(22.7)$ \\
\hline No & $1402(85.1)$ & $705(65.4)$ & $2107(77.3)$ \\
\hline
\end{tabular}

\section{Factors associated with risky sexual behaviour among young people}

Being involved in risky sexual behaviour was regressed against background characteristics, SRH knowledge and self-perceived risk to SRH problems. Tables 3 and 4 show odds ratio estimates at bivariate and multivariate levels respectively for 15-19 and 20-24 year old respondents. For the 15-19 years group, factors associated with risky sexual behaviour after correcting for differences in age included being female versus male (aOR: 1.89, 95\% CI: 1.37-2.61), being out of school versus being in school (aOR: 1.44, 95\% CI: 0.87-2.41), having one parent alive versus having both (aOR: 1.56, 95\% CI: 1.08-2.24), being involved in casual works versus being a student (aOR: 2.08, 95\% CI: 1.27-3.39), being knowledgeable about FP methods (aOR: 3.46, 95\% CI: 1.47-8.14), as well as the respondents' self-perceived risk of being infected with STIs (aOR: 2.88, 95\% CI: 1.72-4.82) (Table 3).

For the 20-24 years old respondents, significant predictors of risky sexual behaviour included living in a rural area (aOR: 1.52, 95\% CI: 1.03-2.24), being female versus male (aOR: $2.10,95 \% \mathrm{CI}: 1.56-2.81$ ), having some primary versus secondary education (aOR: 1.46, 95\% CI: 1.07-2.01), not having a filial or marital relationship with the head of household (aOR: 1.55, 95\% CI: $1.03-$ 2.34 ), and self-perceived risk of pregnancy (aOR: 1.56, 95\% CI: 1.01-2.43) (Table 4). 
Table 3 Factors associated with having engaged in risky sexual behaviour among participants aged 15-19years

\begin{tabular}{|c|c|c|c|c|c|c|c|c|}
\hline \multirow{3}{*}{$\begin{array}{l}\text { Variable } \\
\text { Residence (ref: Rural) }\end{array}$} & \multicolumn{4}{|c|}{ Bivariate analysis } & \multicolumn{4}{|c|}{ Multivariate analysis } \\
\hline & \multirow{2}{*}{$\begin{array}{l}\text { OR } \\
0.80\end{array}$} & \multirow{2}{*}{$\begin{array}{l}p \text {-value } \\
0.27\end{array}$} & \multicolumn{2}{|c|}{$95 \% \mathrm{Cl}$} & \multirow{2}{*}{$\begin{array}{l}\mathrm{aOR} \\
0.80\end{array}$} & \multirow{2}{*}{$\frac{p \text {-value }}{0.41}$} & \multicolumn{2}{|c|}{$95 \% \mathrm{Cl}$} \\
\hline & & & 0.54 & 1.19 & & & 0.48 & 1.35 \\
\hline Marital Status (ref: Ever married) & 0.38 & $<0.001$ & 0.26 & 0.55 & 0.98 & 0.95 & 0.57 & 1.71 \\
\hline Age (Continuous) & 1.60 & $<0.001$ & 1.44 & 1.78 & 1.44 & $<0.001$ & 1.26 & 1.64 \\
\hline Gender (ref: Female) & 1.68 & $<0.001$ & 1.27 & 2.20 & 1.89 & $<0.001$ & 1.37 & 2.61 \\
\hline Schooling Status (ref: In school) & 2.59 & $<0.001$ & 1.96 & 3.42 & 1.44 & 0.16 & 0.87 & 2.41 \\
\hline \multicolumn{9}{|l|}{ Education level (ref: Secondary +) } \\
\hline None & 2.16 & 0.15 & 0.76 & 6.17 & 1.59 & 0.48 & 0.44 & 5.70 \\
\hline Some Primary & 0.95 & 0.69 & 0.72 & 1.24 & 0.89 & 0.55 & 0.62 & 1.29 \\
\hline \multicolumn{9}{|l|}{ Relation to household head (ref: Child) } \\
\hline Head/spouse & 2.00 & $<0.001$ & 1.35 & 2.94 & 1.13 & 0.64 & 0.67 & 1.92 \\
\hline other relative & 1.42 & 0.04 & 1.01 & 2.00 & 1.14 & 0.55 & 0.74 & 1.75 \\
\hline \multicolumn{9}{|l|}{ Parents' Status (ref: Both alive) } \\
\hline Both parents dead & 1.54 & 0.07 & 0.96 & 2.45 & 1.20 & 0.52 & 0.69 & 2.12 \\
\hline One parent alive & 1.80 & $<0.001$ & 1.32 & 2.47 & 1.56 & 0.02 & 1.08 & 2.24 \\
\hline \multicolumn{9}{|l|}{ Occupation (ref: Student) } \\
\hline Peasant & 2.42 & $<0.001$ & 1.69 & 3.46 & 1.11 & 0.70 & 0.65 & 1.91 \\
\hline Casual work & 2.99 & $<0.001$ & 2.14 & 4.19 & 2.08 & $<0.001$ & 1.27 & 3.39 \\
\hline Unemployed & 1.20 & 0.59 & 0.62 & 2.33 & 0.90 & 0.79 & 0.40 & 1.99 \\
\hline \multicolumn{9}{|l|}{ Region (ref: Central 1) } \\
\hline Central 2 & 1.74 & 0.08 & 0.94 & 3.19 & 2.04 & 0.04 & 1.04 & 4.00 \\
\hline East Central & 0.95 & 0.86 & 0.51 & 1.77 & 1.42 & 0.32 & 0.71 & 2.82 \\
\hline Eastern & 1.19 & 0.57 & 0.65 & 2.18 & 1.40 & 0.33 & 0.72 & 2.72 \\
\hline Kampala & 0.89 & 0.81 & 0.36 & 2.20 & 1.27 & 0.67 & 0.43 & 3.78 \\
\hline Karamoja & 2.55 & 0.03 & 1.10 & 5.91 & 2.49 & 0.08 & 0.91 & 6.78 \\
\hline North & 1.49 & 0.22 & 0.79 & 2.81 & 1.49 & 0.29 & 0.72 & 3.09 \\
\hline South West & 1.39 & 0.27 & 0.78 & 2.46 & 1.31 & 0.41 & 0.69 & 2.50 \\
\hline West Nile & 1.82 & 0.06 & 0.97 & 3.43 & 2.35 & 0.02 & 1.17 & 4.73 \\
\hline Western & 2.89 & $<0.001$ & 1.65 & 5.08 & 3.31 & $<0.001$ & 1.77 & 6.18 \\
\hline \multicolumn{9}{|l|}{ SRH Knowledge and Perceived Risk } \\
\hline FP knowledge (ref: No) & 3.64 & $<0.001$ & 1.68 & 7.88 & 3.46 & $<0.001$ & 1.47 & 8.14 \\
\hline Knowledge of STIs (ref: No) & 1.87 & $<0.001$ & 1.23 & 2.85 & 1.41 & 0.16 & 0.87 & 2.29 \\
\hline Knowledge of HIV/AIDS (ref: No) & 0.96 & 0.83 & 0.67 & 1.38 & 0.93 & 0.73 & 0.61 & 1.42 \\
\hline Perceived risk of STIs (ref: None) & 3.25 & $<0.001$ & 2.42 & 4.36 & 2.88 & $<0.001$ & 1.72 & 4.82 \\
\hline Perceived risk of pregnancy (ref: None) & 2.52 & $<0.001$ & 1.91 & 3.32 & 1.01 & 0.96 & 0.62 & 1.66 \\
\hline
\end{tabular}

\section{Discussion}

In a context where sexually transmitted infections and teenage pregnancies are still a major public health problem, and where HIV prevalence seems to be rebounding, it is important to understand the emerging drivers of the epidemic and the opportunities for closer SRH/HIV integration in prevention services. This study goes beyond descriptive statistics about SRH indicators in young people to provide an incisive analysis of the connection between the knowledge - risk perception
- practices continuum. Unpacking this important nexus can help to identify likely sources of stagnation along the continuum.

The high rates of SRH and HIV knowledge observed among respondents confirm our assumption that increasing HIV prevalence among young people and stagnating teenage pregnancy prevalence in Uganda are not primarily due to lack of information among this group. Both younger and older respondents in our study displayed levels of knowledge above $82 \%$, though as expected 
Table 4 Factors associated with having engaged in risky sexual behaviour among participants aged 20-24 years

\begin{tabular}{|c|c|c|c|c|c|c|c|c|}
\hline \multirow{3}{*}{$\begin{array}{l}\text { Variable } \\
\text { Residence (ref: Rural) }\end{array}$} & \multicolumn{4}{|c|}{ Bivariate analysis } & \multicolumn{4}{|c|}{ Multivariate analysis } \\
\hline & \multirow{2}{*}{$\begin{array}{l}\text { OR } \\
1.34\end{array}$} & \multirow{2}{*}{$\begin{array}{l}p \text {-value } \\
0.06\end{array}$} & \multicolumn{2}{|c|}{$95 \% \mathrm{Cl}$} & \multirow{2}{*}{$\frac{\mathrm{aOR}}{1.52}$} & \multirow{2}{*}{$\frac{p \text {-value }}{0.04}$} & \multicolumn{2}{|c|}{$95 \% \mathrm{Cl}$} \\
\hline & & & 0.99 & 1.80 & & & 1.03 & 2.24 \\
\hline Marital Status (ref: Ever married) & 0.74 & 0.02 & 0.57 & 0.95 & 0.87 & 0.44 & 0.60 & 1.25 \\
\hline Age (Continuous) & 1.17 & $<0.001$ & 1.08 & 1.27 & 1.12 & 0.02 & 1.02 & 1.23 \\
\hline Gender (ref: Female) & 1.67 & $<0.001$ & 1.30 & 2.15 & 2.10 & $<0.001$ & 1.56 & 2.81 \\
\hline Schooling Status (ref: In school) & 1.89 & $<0.001$ & 1.38 & 2.60 & 1.27 & 0.42 & 0.71 & 2.28 \\
\hline \multicolumn{9}{|l|}{ Education level (ref: Secondary +) } \\
\hline None & 1.58 & 0.31 & 0.65 & 3.80 & 1.97 & 0.17 & 0.74 & 5.22 \\
\hline Some Primary & 1.28 & 0.06 & 0.99 & 1.66 & 1.46 & 0.02 & 1.07 & 2.01 \\
\hline \multicolumn{9}{|l|}{ Relation to household head (ref: Child) } \\
\hline Head/spouse & 1.64 & $<0.001$ & 1.24 & 2.17 & 1.29 & 0.17 & 0.90 & 1.87 \\
\hline Other relative & 1.62 & 0.01 & 1.12 & 2.33 & 1.55 & 0.04 & 1.03 & 2.34 \\
\hline \multicolumn{9}{|l|}{ Parents' Status (ref: Both alive) } \\
\hline Both parents dead & 1.39 & 0.09 & 0.95 & 2.03 & 1.11 & 0.62 & 0.73 & 1.70 \\
\hline One parent alive & 1.11 & 0.49 & 0.83 & 1.48 & 0.97 & 0.87 & 0.71 & 1.34 \\
\hline \multicolumn{9}{|l|}{ Occupation (ref: Student) } \\
\hline Peasant & 1.73 & 0.01 & 1.17 & 2.56 & 1.03 & 0.93 & 0.52 & 2.04 \\
\hline Casual works & 2.56 & $<0.001$ & 1.74 & 3.75 & 1.48 & 0.23 & 0.78 & 2.79 \\
\hline Unemployed & 1.44 & 0.20 & 0.82 & 2.51 & 1.01 & 0.97 & 0.47 & 2.19 \\
\hline \multicolumn{9}{|l|}{ Region (ref: Central 1) } \\
\hline Central 2 & 1.31 & 0.32 & 0.77 & 2.25 & 1.31 & 0.37 & 0.72 & 2.36 \\
\hline East Central & 1.39 & 0.23 & 0.82 & 2.35 & 1.42 & 0.23 & 0.80 & 2.53 \\
\hline Eastern & 0.87 & 0.60 & 0.53 & 1.44 & 0.95 & 0.84 & 0.56 & 1.62 \\
\hline Kampala & 1.05 & 0.88 & 0.58 & 1.89 & 0.60 & 0.16 & 0.30 & 1.22 \\
\hline Karamoja & 0.85 & 0.68 & 0.39 & 1.84 & 0.79 & 0.60 & 0.33 & 1.90 \\
\hline North & 0.76 & 0.36 & 0.42 & 1.37 & 0.72 & 0.31 & 0.37 & 1.37 \\
\hline South West & 0.81 & 0.39 & 0.50 & 1.31 & 0.72 & 0.23 & 0.42 & 1.22 \\
\hline West Nile & 1.21 & 0.56 & 0.63 & 2.34 & 1.06 & 0.87 & 0.53 & 2.13 \\
\hline Western & 1.14 & 0.61 & 0.69 & 1.88 & 1.13 & 0.65 & 0.66 & 1.96 \\
\hline \multicolumn{9}{|l|}{ SRH Knowledge and Perceived Risk } \\
\hline FP knowledge (ref: No) & 1.82 & 0.24 & 0.67 & 4.97 & 1.40 & 0.53 & 0.49 & 4.05 \\
\hline Knowledge of STIs (ref: No) & 1.11 & 0.64 & 0.71 & 1.75 & 1.07 & 0.78 & 0.65 & 1.76 \\
\hline Knowledge of HIV/AIDS (ref: No) & 1.42 & 0.12 & 0.91 & 2.21 & 1.55 & 0.08 & 0.95 & 2.53 \\
\hline Perceived risk of STIs (ref: None) & 1.27 & 0.07 & 0.98 & 1.65 & 0.84 & 0.45 & 0.53 & 1.32 \\
\hline Perceived risk of pregnancy (ref: None) & 1.32 & 0.03 & 1.03 & 1.70 & 1.56 & 0.05 & 1.01 & 2.43 \\
\hline
\end{tabular}

the 20-24 year olds had higher SRH awareness across all surveyed areas. However, the disparity of up to 9 percentage points in average SRH/HIV knowledge levels among respondents (from 94\% average knowledge about FP to $86 \%$ average knowledge about HIV) points to a missed opportunity to further integrate SRH/HIV information and educational campaigns for young people in Uganda, while keeping in mind that SRH/HIV prevention interventions focused exclusively on providing information have been shown to link weakly to risk behaviour reductions
[22-25]. Our results also point to the need of repurposing the delivery of SRH/HIV messages in primary care.

Whereas SRH knowledge among respondents is high, our analysis shows it is also a significant predictor of risky sexual behaviour. Contrary to what could be expected, more knowledgeable young people seem also to be more likely to have engaged in risky sexual behaviour. This is particularly the case for FP knowledge among 15-19 year olds, which might be indicative of this young group's tendency to source SRH information from their 
existing sexual networks as they experiment and gain more experience. The same variable is not a significant predictor of risky sexual behaviour among the older group (20-24 year olds), which face a different set of factors associated with risky sexual behaviour.

Overall, our findings on knowledge levels and individual behaviour support other studies that claim protective FP/STI/HIV knowledge alone does not necessarily result in safe-sex behaviour [26, 27]. In particular, risky contraceptive use behaviour observed among young people with significant SRH knowledge levels might be partially attributed to negative norms, fears and attitudes that affect their uptake of condoms and other contraceptives, as well as to challenges accessing services [28-31]. Closer integration of FP and HIV counselling and testing services for young people is therefore a pending deliverable and an opportunity to improve contraceptive uptake among young Ugandans displaying risk sexual behaviours that expose them to HIV [32].

Nearly 1 in 2 young respondents reported feeling at risk of SRH problems, with perceived risk of STIs (including HIV) featuring consistently higher (average 52\%) than pregnancy risk (average 45\%) across both younger and older respondents. While the perceived risk trend was seen to increase with age, these results should be interpreted in light of the tendency of younger people to overestimate risk [33].

The high levels of self-perceived vulnerability reported by respondents would be expected to contribute to a firm personal motivation to reduce risk exposure. However, our research findings indicate the contrary: Both self-perceived risk of STIs (including HIV) among the younger group and vulnerability to pregnancy among the older group are associated with risky instead of protective sexual behaviour. This is not an unusual finding, attributed by Millestein et al. to the type of measure used (nonconditional) and the cross-sectional study design [33]. Our results might therefore indicate that self-perceived vulnerability is a reflection of risky sexual behaviour, although causality cannot be established. Personal motivation to reduce sexual risk behaviour might also be influenced by social factors and perceived social norms [34-37], which were variables not included in our analysis.

Our research supports the findings from other studies $[37,38]$ that certain social networks and institutions might have a protective role against risky sexual behaviour by young people. We found in particular that school enrolment among the age group 15-19 seems to have a protective effect on sexual behaviour, while doing casual work instead of studying was associated with increased sexual risk behaviours among this age group. These results support the conclusions from prior studies. Research by Hargreaves et al. found that among unmarried and rural young South Africans aged 14-25 years, school attendance was protective due to the structure of sexual networks associated with lower-risk sexual behaviours [39], while Behrman and De Neve et al. highlighted completion of primary and secondary education as having positive effects on exposure to sexual activity and reduction in the cumulative risk of HIV infection [40, 41]. Educational achievement among the 20-24 year olds was also found to have a protective effect on sexual behaviour, which supports findings from literature pointing at decreased HIV prevalence and less risky sexual behaviour among the more educated $[42,43]$.

Another important social institution with direct effect over young people's risky sexual behaviour is the family [44]. Our results indicate that single orphanhood among the younger respondent group and lack of a filial or marital relationship to the head of household among the older group were significant variables affecting risky sexual behaviour. This is supported by other research that points at limited perceived parental monitoring and orphanhood (both single and double) to be associated with poorer health behaviours $[45,46]$.

Our findings reaffirm existing programming recommendations for SRH/HIV prevention, including the need to focus not only on individual-level behavioural interventions, but also on social and structural factors and institutions that affect individual behaviour [47]. Our research also emphasizes that certain demographic groups (young women and rural residents) seem to also be more vulnerable to higher risk sexual practices, which calls for SRH/HIV prevention programmes to further target these vulnerable groups.

While this study contributes to the existing evidence on knowledge and risk perceptions, and their association with risky sexual behaviour, the results presented should be examined taking into account a few study limitations. These include measurement of various socio-behavioural variables on the basis of composite indicators such as SRH knowledge, challenges in adequately assessing attitudes and perceptions (e.g. risk perception), as well as reliance on self-reports for sensitive questions related to risky sexual behaviour which could lead to underestimation of its prevalence. To mitigate these challenge however, we used tools that have already been tested and validated for use in the context where this study was conducted. In addition, while we acknowledge that there are multiple social and structural factors that influence individual risky sexual behaviour (social norms, service accessibility and quality, economic pressures), our study did not explore in depth these reasons. Finally, the cross-sectional nature of the research inhibits our ability to establish cause and effect for certain indicators of interest. 


\section{Conclusions}

Our study found that although respondent levels of knowledge about FP, STIs and HIV were high, young people also had a high self-perceived SRH/HIV risk and displayed significant levels of risky sexual behaviour. These trends were significantly higher among the 20-24 age group than among 15-19 year olds. This seems to point at a lack of functional skills among young people to avert SRH/HIV related risks.

We also found that being female, being out of school or involved in casual work, being a single orphan, being knowledgeable about FP, and perceiving oneself to be at risk of acquiring an STI/HIV were significant predictors of risky sexual behaviour among 15-19 year olds. Associated factors particular to the 20-24 year old group included being resident in rural areas, not having reached secondary education, not having a filial or marital relationship with the head of household, and perceiving oneself to be at risk of an unwanted pregnancy. Our findings contribute to the available evidence that risky sexual sexual behaviour is not only a function of adequate disease prevention knowledge, but also of young people's ability to engage in preventive behaviour [48], of their positive engagement in surrounding social structures (school and family) and of their ability to negotiate existing social norms.

Given that one in five young Ugandans are engaged in risky sexual behaviour, there is a clear need to scale up SRH/HIV prevention programs that adopt a holistic approach to reduction of risky sexual behaviour. This must be done by combining individual level interventions through information, risk awareness, skill development and discussion of cost-benefit calculations involved in the adoption of SRH/HIV preventive behaviours with interventions targeting social structures affecting individual behaviour.

A French translation of this article has been included as Additional file 1.

A Portuguese translation of the abstract has been included as Additional file 2.

\section{Additional files}

Additional file 1: Translation of this article into French. (PDF $266 \mathrm{~kb}$ )

Additional file 2: Translation of the abstract of this article into

Portuguese. (PDF $271 \mathrm{~kb}$ )

\section{Abbreviations}

EA: Enumeration Area; FP: Family Planning; HIV: Human Immunodeficiency Virus; SDG: Sustainable Development Goal; SRH: Sexual and Reproductive Health; STI: Sexually Transmitted Infection; UBOS: Uganda Bureau of Statistics

\section{Acknowledgements}

The authors wish to thank $\mathrm{AH}$ Consulting for its contribution to study design and for data acquisition.

\section{Funding}

This study was funded by the Department for International Development (UK) and Packard Foundation. The funders were not involved in the design of the study and/or collection, analysis and interpretation of data, and/or in writing the manuscript.

The journal supplement is made possible by the generous support of the American People through the United States Agency for International Development (USAID) in partnership with United Nations Population Fund (UNFPA) and The Joint United Nations Program on HIV/AIDS (UNAIDS). The views expressed in this publication are solely the opinions of the authors and do not necessarily reflect the official policies of the USAID, UNFPA or UNAIDS, nor does mention of the department or agency names imply endorsement by the U.S. Government, UNFPA or UNAIDS.

\section{Availability of data and materials}

The datasets used and/or analyzed during the current study are available from the corresponding author on reasonable request and with permission of the Institutional Review Board.

\section{About this supplement}

This article has been published as part of BMC Public Health, Volume 19 Supplement 1, 2019: Effective Integration of Sexual Reproductive Health and HIV Prevention, Treatment, and Care Services across sub-Saharan Africa: Where is the evidence for program implementation?

The full contents, including French, Portuguese and English language versions, are available online: https://bmcpublichealth.biomedcentral.com/articles/ supplements/volume-19-supplement-1 and https://reproductive-healthjournal.biomedcentral.com/articles/supplements/volume-16-supplement-1.

\section{Authors' contributions}

D.T.K. participated in the design of study, analysis and interpretation of data, and drafting the article. R.P.G. and R.W.M. participated in the design of study, interpretation of data, and drafting the article. All authors read and approved the final manuscript.

\section{Ethics approval and consent to participate}

Ethical approval for the study was obtained from Mildmay Uganda Research Ethics Committee (\#REC REF 0312-2015) and research approval from the Uganda National Council of Science and Technology (SS 4018) in 2016.

Participation in the research was based on full informed consent of respondents, including verbal consent from parents/guardians for those less than 18 years of age.

\section{Consent for publication}

Not applicable.

\section{Competing interests}

The authors declare that they have no competing interests.

\section{Publisher's Note}

Springer Nature remains neutral with regard to jurisdictional claims in published maps and institutional affiliations.

\section{Author details}

${ }^{1}$ United Nations Population Fund (UNFPA), Kampala, Uganda. ${ }^{2}$ African Population and Health Research Center, Manga Cl, Nairobi, Kenya. ${ }^{3}$ School of Public Health, Makerere University, Kampala, Uganda. ${ }^{4}$ School of Statistics and Planning, Makerere University, Kampala, Uganda.

Published: 29 May 2019

References

1. WHO, UNFPA, IPPF, UNAIDS. Sexual and reproductive health and HIV/AIDS: A framework for priority linkages. London, New York and Geneva: World Health Organization/United Nations Population Fund/International Planned Parenthood Federation/Joint United Nations Programme on HIV/AIDS; 2005.

2. WHO, UNFPA, IPPF, UNAIDS, USCF. Sexual and reproductive health and HIV linkages: Evidence review and recommendations. Geneva, New York, London, San Francisco: World Health Organization, United Nations Population Fund, international Planned Parenthood Federation, joint United Nations Programme on HIV/AIDS, University of California san Francisco; 2009. 
3. Germain A, Dixon-Mueller R, Sen G. Back to basics: HIV/AIDS belongs with sexual and reproductive health. Bull World Health Organ. 2009. https://doi org/10.2471/BLT.09.065425.

4. Kennedy CE, Spaulding AB, Brickley DB, Almers L, Mirjahangir J, Packel L, Kennedy GE, Mbizvo M, Collins L, Osborne K. Linking sexual and reproductive health and HIV interventions: a systematic review. J Int AIDS Soc. 2010. https://doi.org/10.1186/1758-2652-13-26.

5. Druce N, Dickinson C, Attawell K, White AC, Standing H. Strengthening linkages for sexual and reproductive health, HIV and AIDS: Progress, barriers and opportunities for scaling up. London: DFID Health Resource Centre; 2006.

6. Dickinson C, Attawell K, Druce N. Progress on scaling up integrated services for sexual and reproductive health and HIV. Bull World Health Organ. 2009. https://doi.org/10.2471/BLT.08.059279.

7. IPPF, UNFPA, WHO, UNAIDS, GNP+, ICW, Young Positives. Rapid assessment tool for sexual \& reproductive health and HIV linkages: a generic guide. London: IPPF, UNFPA, WHO, UNAIDS, GNP+, ICW and Young Positives; 2009.

8. UNAIDS. 90-90-90. An ambitious treatment target to help end the AIDS epidemic. Geneva: Joint United Nations Programme on HIV/ AIDS; 2014.

9. UNAIDS. The sustainable development goals and the HIV response. Stories of putting people at the Centre. Geneva: Joint United Nations Programme on HIV/AIDS; 2017

10. Askew I, Berer M. The contribution of sexual and reproductive health services to the fight against HIV/AIDS: a review. Reprod Health Matters. 2003;11(22):51-73.

11. Government of Uganda, UNFPA. National dialogue on SRHR/HIV and SGBV integration report, 1st - 2nd November 2017. Entebbe: Unpublished; 2017.

12. Republic of Uganda. National strategic plan for HIV\&AIDS 2011/12 -2014/15. Revised. Kampala; 2012.

13. Republic of Uganda National strategy for integration of sexual and reproductive health and rights and HIV/AIDS. Kampala: Ministry of Health; 2012.

14. Government of Uganda. Presidential fast-track initiative on ending HIV \& AIDS in Uganda. A presidential handbook. Kampala; 2017.

15. Inter-agency Working Group on SRH and HIV Linkages. SRH and HIV linkages compendium. Indicators \& related assessment tools. London: IPPF, UNFPA, WHO; 2014.

16. Ministry of Health. Press Statement. Release of preliminary results of the 2016 Uganda population HIV impact assessment. 2017. www.health.go.ug/ download/file/fid/1505. Accessed 1 Mar 2018.

17. UBOS. Young people: The untapped resource for development. Thematic series based on the National Population and Housing Census 2014. Kampala: Uganda Bureau of Statistics; 2017.

18. IPPF, UNFPA, WHO, UNAIDS. Uganda. Rapid assessment of SRH and HIV linkages. Kampala; 2012.

19. UNDESA. Designing household survey samples: practical guidelines. Series F no.98. New York: United Nations Department of Economic and Social Affairs; 2005

20. Ministry of Education and Sports. National sexuality education framework. Kampala; 2018.

21. UBOS. The national population and housing census 2014 - Main report. Kampala: Uganda Bureau of Statistics; 2016.

22. Bazargan M, Kelly EM, Stein JA, Husaini BA, Bazargan SH. Correlates of HIV risk-taking behaviors among African-American college students: the effect of HIV knowledge, motivation, and behavioral skills. J Natl Med Assoc. 2000; 92:391-404.

23. Helweg-Larsen M, Collins BE. A social psychological perspective on the role of knowledge about AIDS in AIDS prevention. Curr Dir Psychol Sci. 1997. https://doi.org/10.1111/1467-8721.ep11512614.

24. Fisher JD, Fisher WA. Theoretical approaches to individual-level change in HIV risk behavior. In: Peterson JL, DiClemente RJ, editors. Handbook of HIV prevention. Boston: Springer; 2000. p. 3-55.

25. Swenson RR, Rizzo CJ, Brown LK, et al. HIV knowledge and its contribution to sexual health behaviors of low-income African American adolescents.

J Natl Med Assoc. 2010. https://doi.org/10.1016/S0027-9684(15)30772-0.

26. Hulton LA, Cullen R, Khalokho SW. Perceptions of the risks of sexual activity and their consequences among Ugandan adolescents. Stud Fam Plan. 2000. https://doi.org/10.1111/j.1728-4465.2000.00035.x.

27. Gallant M, Maticka-Tyndale E. School-based HIV prevention programmes for African youth. Soc Sci Med. 2004. https://doi.org/10.1016/S02779536(03)00331-9.
28. Frost JJ, Lindberg LD, Finer LB. Young adults' contraceptive knowledge, norms and attitudes: associations with risk of unintended pregnancy. Perspect Sex Reprod Health. 2012. https://doi.org/10.1363/4410712.

29. Haider TL, Sharma M. Barriers to family planning and contraception uptake in sub-Saharan Africa: a systematic review. Int Q Community Health Educ 2012-2013; doi:https://doi.org/10.2190/IQ.33.4.g.

30. Chandra-Mouli V, McCarraher DR, Phillips SJ, Williamson NE, Hainsworth G. Contraception for adolescents in low and middle income countries: needs, barriers, and access. Reprod Health. 2014. https://doi.org/10.1186/1742-4755-11-1.

31. Nalwadda G, Mirembe F, Byamugisha J, Faxelid E. Persistent high fertility in Uganda: young people recount obstacles and enabling factors to use of contraceptives. BMC Public Health. 2010. https://doi.org/10.1186/1471-2458$10-530$.

32. Lindegren ML, Kennedy CE, Bain-Brickley D, Azman H, Creanga AA, Butler LM, Spaulding AB, Horvath T, Kennedy GE. Integration of HIV/AIDS services with maternal, neonatal and child health, nutrition, and family planning services. Cochrane Database Syst Rev. 2012. https://doi.org/10.1002/ 14651858.CD010119.

33. Millstein SG, Halpern-Felsher BL. Perceptions of risk and vulnerability. In Fischhoff B, Nightingale EO, lannotta JG, editors. Adolescent risk and vulnerability: Concepts and measurement. Washington D.C.: National Academies Press; 2001

34. Fisher AW, Fisher JD, Harman J. The information-motivation-behavioral skills model: a general social psychological approach to understanding and promoting health behavior. In: Suls J, Wallston KA, editors. Social psychological foundations of health and illness. Malden: Blackwell Publishing Ltd; 2003.

35. Chang SJ, Choi S, Kim SA, Song M. Intervention strategies based on information-motivation-behavioral skills model for health behavior change: a systematic review. Asian Nursing Research. 2014. https://doi. org/10.1016/j.anr.2014.08.002.

36. Marston C, King E. Factors that shape young people's sexual behaviour: a systematic review. Lancet. 2006. https:/doi.org/10.1016/S0140-6736(06)69662-1.

37. Latkin CA, Knowlton AR. Micro-social structural approaches to HIV prevention: a social ecological perspective. AIDS Care. 2005. https://doi.org/10.1080/ 09540120500121185

38. Auerbach JD, Parkhurst JO, Cáceres CF. Addressing social drivers of HIV/AIDS for the long-term response: conceptual and methodological considerations. Glob Public Health. 2011. https://doi.org/10.1080/ 17441692.2011.594451.

39. Hargreaves JR, Morison LA, Kim JC, Bonell CP, Porter JD, Watts C, Busza J, Phetla G, Pronyk PM. The association between school attendance, HIV infection and sexual behaviour among young people in rural South Africa. J Epidemiol Community Health. 2008. https://doi.org/10.1136/jech.2006. 053827

40. Behrman JA. The effect of increased primary schooling on adult women's HIV status in Malawi and Uganda: universal primary education as a natural experiment. Soc Sci Med. 2015. https://doi.org/10.1016/j.socscimed.2014.06.034

41. De Neve JW, Fink G, Subramanian SV, Moyo S, Bor J. Length of secondary schooling and risk of HIV infection in Botswana: evidence from a natural experiment. Lancet Glob Health. 2015. https://doi.org/10.1016/S2214109X(15)00087-X

42. Hargreaves JR, Bonell CP, Boler T, Boccia D, Birdthistle I, Fletcher A, Pronyk PM, Glynn JR. Systematic review exploring time trends in the association between educational attainment and risk of HIV infection in sub-Saharan Africa. AIDS. 2008. https://doi.org/10.1097/QAD.0b013e3282f2aac3.

43. Glynn JR, Caraël M, Buvé A, Anagonou S, Zekeng L, Kahindo M. Musonda R. for the study group on heterogeneity of HIV epidemics in African cities. Does increased general schooling protect against HIV infection? A study in four African cities. Tropical Med Int Health. 2004. https://doi.org/10.1046/j. 1365-3156.2003.01168.x.

44. Perrino T, Gonzalez-Soldevilla A, Pantin H, Szapocznik J. The role of families in adolescent HIV prevention: a review. Clin Child Fam Psychol Rev. 2000;3(2):81-96.

45. DiClemente RJ, Wingood GM, Crosby R, Sionean C, Cobb BK, Harrington K, Davies S, Hook EW 3rd, Oh MK. Parental monitoring: association with adolescents' risk behaviors. Pediatrics. 2001;107(6):1363-8.

46. Birdthistle IJ, Floyd S, Machingura A, Mudziwapasi N, Gregson S, Glynn JR From affected to infected? Orphanhood and HIV risk among female adolescents in urban Zimbabwe. AIDS. 2008. https://doi.org/10.1097/ QAD.0b013e3282f4cac7. 
47. Dean HD, Fenton KA. Addressing social determinants of health in the prevention and control of HIV/AIDS, viral hepatitis, sexually transmitted infections, and tuberculosis. Public Health Rep. 2010. https://doi.org/10. 1177/00333549101250S401.

48. Fisher JD, Fisher WA, Williams SS, Malloy TF. Empirical tests of an information-motivation-behavioral skills model of AIDS preventive behavior. Health Psychol. 1994;13:238-50.

- fast, convenient online submission

- thorough peer review by experienced researchers in your field

- rapid publication on acceptance

- support for research data, including large and complex data types

- gold Open Access which fosters wider collaboration and increased citations

- maximum visibility for your research: over $100 \mathrm{M}$ website views per year

At BMC, research is always in progress. 